\title{
THE EFFECT OF ALOE VERA GEL EDIBLE COATING AND GLYCEROL ON THE PHYSICOCHEMICAL CHARACTERISTICS OF RED GRAPES (Vitis vinifera L.)
}

\author{
Irna Dwi Destiana*, Zulfa Nur Anisa, Nurul Mukminah \\ Department of Agroindustry, Politeknik Negeri Subang \\ JI. Brigjen Katamso No. 37 (Belakang RSUD Subang) Dangdeur Subang 41212 \\ ${ }^{*}$ Correspondence Author, Email: irnadwidestiana@gmail.com
}

\begin{abstract}
Red grape (Vitis vinifera L.) is easy to get perishable and wrinkles/wilt, brown in color, and soft fruit flesh. one of the benefits of edible coating is that it can protect products from microbiological damage. The ability of aloe vera as an antimicrobial can be a potential ingredient for making edible coatings. Besides, the use of aloe vera as an edible coating is also very easy and affordable (cheap). The purposes of this study are to determine the effect of glycerol addition and the best treatment of aloe vera edible coating on the quality of the red grape. The experiment used a completely randomized design (CRD) as an experimental design with 4 treatment factors, namely the concentration of glycerol $(P 1=0 \%, P 2=3 \%$, $P 3=5 \%, P 4=7 \%)$. Each concentration was repeated three times. The parameters observed were physicochemical characteristics (weight reduction, $\mathrm{pH}$, total titrated acid), hedonic quality test (color, aroma, texture). The results showed that the treatment of 3\% glycerol was the best treatment since it could maintain the condition of the fruit well during storage, especially weight reduction, aromas, and textures. Parameters that highly affect the quality of red grapes are texture and weight loss.
\end{abstract}

Keywords: Aloe vera, Edible coating, Glycerol, Red grape.

\section{INTRODUCTION}

Fruits have become alternatives to fulfill our body's needs of nutritional substances, especially vitamins. Fruit consumption will continue to increase to meet these needs. However, the fruit should also have good quality. Most of the time, consumers receive subgrade/rotten fruits with less attractive appearance.

Red grapes (Vitis vinifera L.) are non-climacteric fruits which generally have higher selling price and contain vitamins A, C, B. Besides, it is also rich in polyphenolic compounds. Subgrade red grapes are commonly found during the serving and storage process, as they become wrinkled/withered, of a brownish color, and the flesh of the fruit is soft. Some research has been conducted regarding the application of edible coating on fruits. The application of the edible coating on red grapes can maintain their quality and extend their shelf-life by minimizing the damage caused by physical, chemical, and microbiological changes (Cornelia, 2017).

Any damage to red grapes can be managed by using the coating method. The coating is a method of applying a thin layer to the surface of the fruit which can inhibit any discharge of gas, steam, water, and direct contact with oxygen so that the process of ripening and browning reaction of fruits can be slowed down. The application of an edible coating that will be carried out in this research is the preparation of edible coating derived from aloe vera gel (Aloe vera L.). Aloe vera (Aloe vera L.) is one of the plants containing polysaccharides (glucomannan or pectic acid), organic materials, and other inorganic substances. Some components contained in Aloe vera (Aloe vera L.) can inhibit post-harvest damage in agricultural products; these include glucomannan which is quite beneficial to humans as it has antimicrobial as well as increase the proliferation of the injured cells (Simanjorang, 2017). The 
ability of aloe vera as an antimicrobial can be a potential ingredient for making edible coatings, where one of the benefits of edible coating is that it can protect products from microbiological damage. Aloe vera contains polysaccharides and lignin which can withstand the loss of fluid from the surface of the fruit skin, so as to reduce the rate of senescence (wrinkled/withered) and maintain the freshness of the fruit. Besides that, the use of aloe vera as an edible coating is also very easy and affordable (cheap).

Glycerol is effectively used as a plasticizer since it can produce a more flexible and smoother film without any stiff texture so that it does not damage the color and the appearance of the fruit. The addition of glycerol can increase the elasticity of the film as well as inhibit gas exchange and the water absorption process (Nahwi, 2016).

The purpose of this study is to determine the impact of the addition of glycerol in the aloe vera edible coating on the physicochemical characteristics of red grapes, which include weight reduction, $\mathrm{pH}$, and Titrated Acid Total (TAT). Besides, this study aims at determining the effect of the addition of glycerol on the application of the edible coating on the hedonic quality (aroma, texture, and color).

\section{METHODOLOGY}

\section{Materials}

The materials used in this study are aloe vera solution and red grapes. The p.a (pro analysis) chemicals used were $0.2 \%$ ascorbic acid, $0.45 \%$ citric acid, glycerol, distilled water, $\mathrm{NaOH}$, pp indicators.

\section{Equipment}

Equipment used in this research were blender, filter, basin, stirrer, plastic cutting boards, knife. Some types of equipment used for the analysis process were hot plate, Erlenmeyer, beaker glass, measuring cup, funnel, burette, pipette volume, mixer, spatula, glass wristwatch, mortal, pastle, clamps, stative, volumetric flask, $\mathrm{pH}$ paper, filter paper, digital scales.

\section{Research Design}

The experimental design for this research was the Completely Randomized Design (CRD) with one factor and four treatments and three repetitions. The factors used were glycerol concentration of $0 \%, 3 \%, 5 \%$, and $7 \%$. The Data obtained was then transformed and then proceeded to the statistical measurement process by using ANOVA (Analysis of Variance) with a level of significance of $5 \%$. The process continued with the Duncan test by leveraging SPSS (Statistical Package for the Social Sciences) media processing.

\section{Steps in Research Process}

This research was started with the preparation of aloe vera edible coating. The making of aloe vera gel was based on the process of producing aloe vera drink according to (Kismaryanti, 2007) with some modification by providing a variety of treatment such as washing, heating, as well as acid addition. Washing technique optimization was performed to remove yellow liquid that can degrade the quality of the gel. Then, the edible coating was applied to the red grapes by using the dipping (immersion) technique. It was then drained and aerated. The next process was storing it at room temperature and conducting observations. The observation parameters included the physicochemical characteristics (weight reduction, $\mathrm{pH}$, TAT) and hedonic quality (aroma, texture, color). The data collection process was performed every 2 days until the 13th day of observation. However, the data of weight reduction, texture, and color were taken every day.

\section{Methods}

The process of making aloe vera gel solution was started with sorting and washing aloe vera, trimming and filleting, rinsing to remove the yellow sap, crushing process of the aloe vera gel ( \pm 2 minutes), and adding the distilled water, filtering, stirring and heating at the temperature of $60_{-}{ }^{\circ} \mathrm{C}$, adding $0.2 \%$ ascorbic acid and citric acid during the cooling process at 
the room temperature of $\pm 30_{-}^{\circ} \mathrm{C}$. Then, the homogenization process was initiated and the solution was ready for use. The solution obtained was then added with glycerol at various concentrations. Fresh grapes were dipped in four different coating solution formula, namely:

\begin{tabular}{cl}
\hline Treatments & Formulation \\
\hline P1 & Gel coating Solution of pure aloe vera (without the addition of glycerol) \\
P2 & Gel coating solution of aloe vera with the addition of $3 \%$ glycerol $(3 \mathrm{ml})$ \\
P3 & Gel coating solution of aloe vera with the addition of $5 \%$ glycerol $(5 \mathrm{ml})$ \\
P4 & Gel coating solution of aloe vera with the addition of $7 \%$ glycerol $(7 \mathrm{ml})$ \\
\hline
\end{tabular}

\section{Analytical Procedure}

a. Weight reduction (Gardjito and Wardana, 2003)

$\%$ Weight reduction $=\frac{\text { Initial weight }(\text { gram })-\text { Final weight }(\text { gram })}{\text { Initial weight(gram) }} \times 100 \%$

\section{b. Degree of acidity (pH)}

The measurement of the degree of acidity $(\mathrm{pH})$ by using a universal $\mathrm{pH}$.

c. Titrated Acid Total (TAT) (Sudarmadji et al., 1997)

The grapes were mashed and put into a volumetric flask. It was then added with distilled water to $100 \mathrm{ml}$, stirred until evenly distributed, and then filtered by using filter paper. After that, $25 \mathrm{ml}$ of filtrate was taken and added with 2-3 drops of phenolphthalein (PP) indicator. The sample was then titrated by using $0.1 \mathrm{~N} \mathrm{NaOH}$ until the color was changing to pink. The type of acid measured in the TAT of grapes is tartaric acid. The formula to calculate TAT levels are:

$\% \mathrm{TAT}=\frac{\mathrm{ml} \text { of } \mathrm{NaOH} \times \mathrm{N} \mathrm{NaOH} \times \text { Grek }}{\text { Material Volume }(\mathrm{ml})}$

\section{d. Hedonic quality test}

The quality observation was subjectively performed by paying attention to any changes that occurred during the observation process, such as aroma, texture/hardness, color (by using color assist application) on the grapes every 2 days for 2 weeks.

\section{RESULTS AND DISCUSSION}

\section{Weight Reduction}

Weight reduction occurs during product storage. This reduction process happened as a result of the continuing respiration and transpiration process. The process of respiration occurred in the fruit is the biological process by which oxygen is absorbed to burn the organic ingredients in the fruit to produce energy. This is followed by the release of the residue of respiration in the form of carbon dioxide and water. Water, gas, and energy are produced (in the form of heat) and will be evaporated so that the weight of the fruit decreased. Based on the results of the analysis of variance, it showed that the treatment of the edible coating has an insignificant value to weight reduction. Weight reduction in P3 was $10.24 \%$. This means that the treatment is able to inhibit respiration better so that the weight reduction of the fruit can also be inhibited. Meanwhile, the treatment with the highest glycerol concentration has the highest reduction. This is affected by the amount of weight reduction that is comparable with the transpiration and respiration process. The different glycerol concentration affects the levels of $\mathrm{CO}_{2}, \mathrm{O}_{2}$, and water content of the fruit. The higher concentration of glycerol does not a positive impact on the fruit, while the treatment without glycerol and low glycerol concentration (3\% and 5\%) gives an impact in inhibiting the rate of weight reduction. It means that the edible coating is capable of forming a good coating to inhibit the respiration and transpiration process (Prabawa \& Sugianti, 2016).

Table 1. Average Weight Reduction, $\mathrm{pH}$, and TAT Fruit Red Grapes During Storage

$\begin{array}{llll}\text { Treatments } & \text { Weight Reduction (gram) } & \mathrm{pH} & \text { TAT (\%) }\end{array}$


The Effect of Aloe Vera Gel Edible Coating and Glycerol - Destiana, dkk Jurnal Pangan dan Agroindustri Vol. 9 No.3: 188-195, Juli 2021

\begin{tabular}{llll}
\hline P1 & $10.60 \pm 0.06^{\mathrm{a}}$ & $4.10 \pm 0.12^{\mathrm{a}}$ & $0.38 \pm 0.05^{\mathrm{a}}$ \\
P2 & $12.51 \pm 0.21^{\mathrm{a}}$ & $4.17 \pm 0.06^{\mathrm{a}}$ & $0.38 \pm 0.15^{\mathrm{a}}$ \\
P3 & $10.24 \pm 0.13^{\mathrm{a}}$ & $4.31 \pm 0.03^{\mathrm{a}}$ & $0.35 \pm 0.22^{\mathrm{a}}$ \\
P4 & $11.16 \pm 0.14^{\mathrm{a}}$ & $4.05 \pm 0.15^{\mathrm{a}}$ & $0.33 \pm 0.35^{\mathrm{a}}$ \\
\hline
\end{tabular}

Coating treatment with varying glycerol formulations is expected to decrease the rate of weight reduction. The results of the weight reduction for 13 days with the addition of $0 \%, 3 \%$, $5 \%$, and $7 \%$ glycerol can be seen in (Fig.1.).

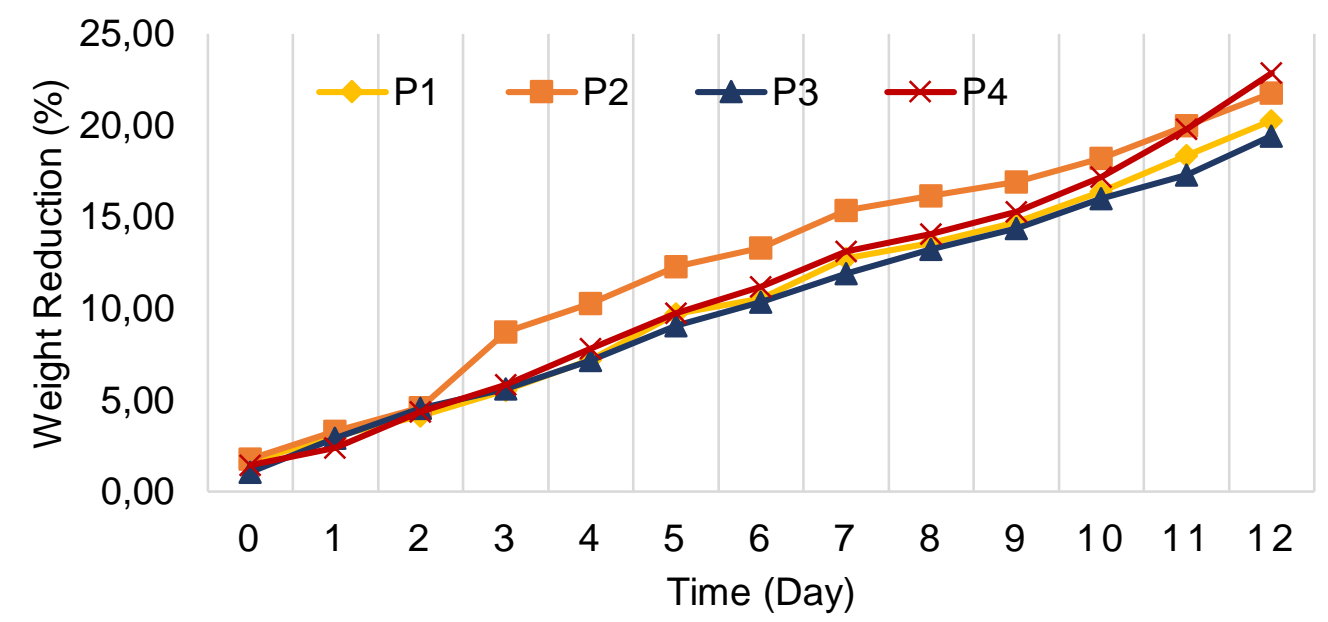

Figure 1. The chart of the impact glycerol level of edible coating on the decrease in weight reduction

According to (Fig.1.), the coating of edible coating affects the weight reduction where the lowest decrease value for 13 days was found in P3 treatment. Besides, the highest decrease value of the weight reduction was found on the P4 treatment. This happens because the respiration process occurred in the fruit is a biological process where the oxygen is absorbed to burn the organic ingredients in the fruit to produce energy. It is then followed by the release of the respiration residue in the form of carbon dioxide and water. Water, gas, and energy are produced (in the form of heat) and will evaporate so that the weight of the fruit decreased. The loss of water cannot be inhibited since the coating used is hydrophilic (Prasotio, 2015).

The quality of red grapes is strongly affected by the storage duration as well as the applied treatment. Usually, the term 'reduction' is only construed as a part of the weight that is lost due to a certain process. However, reduction by quantity is a reduction that occurs and can be measured by the weight unit. Reduction by quality is any reduction that leads to a reduction in the nutritional value of the foodstuff. Weight reduction is usually related to the reduction by quality and quantity, cost, energy, and time (Marwina et al., 2016).

\section{Degree of Acidity (pH) Test}

Based on the result of the statistical analysis of the advanced Duncan test performed, the $\mathrm{pH}$ value of the glycerol concentration coating treatment stored at room temperature does not differ significantly from the $\mathrm{pH}$ of red grapes stored at room temperature. $\mathrm{P} 3$ treatment of glycerol obtains the highest $\mathrm{pH}$ value, that is 4,31 . An increase in $\mathrm{pH}$ is caused by an increase in the amount of sugar of the fruit so that the amount of acid is decreased. This is in line with the research results (Cornelia, 2017) which states that the interaction between the treatment of the coating does not have a significant impact on the $\mathrm{pH}$ of red grapes, and the highest $\mathrm{pH}$ value of red grapes, is 4.41 , which occurs since during storage, the organic acids contained in red grapes are used in the process of respiration. Therefore, the amount of acid in the red grapes decreases and causes the $\mathrm{pH}$ to increase.

The $\mathrm{pH}$ value of the fruit is related to the organic acids contained therein. The decrease in acidity is characterized by an increase in $\mathrm{pH}$ value. The low $\mathrm{pH}$ value indicates that acid 
organic contained in the fruit is still in good condition. The rise in $\mathrm{pH}$ value is caused by the decrease of the formation of acids and a decrease in the content of organic acids during storage. The acidity change of the red grapes is different depending on the level of maturity and storage temperature (Kismaryanti, 2007).

Based on the results, it showed that in the P3 treatment, glycerol had the highest $\mathrm{pH}$ value, while in the $\mathrm{P} 1$ treatment, glycerol had the lowest $\mathrm{pH}$ value. Nevertheless, the $\mathrm{pH}$ value of all treatments was the same, which was 4 . This is because grapes contain tartaric acid that serves as a $\mathrm{pH}$ regulator, so the $\mathrm{pH}$ in grapes remained the same. The higher $\mathrm{pH}$ on red grapes indicates that starch substance has transformed into sugar in the fruit during the ripening process. PH measurement can not be separated from the level of maturity of the fruit since fruit maturity is generally indicated by the ratio of sugar and acid (Taringan, 2015).

\section{Titratable Acidity (TTA)}

Based on (Table 1), the TTA statistical analysis of red grapes shows that the concentration of glycerol in coating treatment is not significantly different from the titratable acidity of red grapes stored at room temperature. The $\mathrm{pH}$ and acidity values will change with the metabolic rate of the fruit. This is in line with the research of (Cornelia, 2017) stating that the TTA of red grapes stored at room temperature did not differ significantly. Grapes have a fairly low respiration rate, so the changes that occur during storage are insignificant. The use of aloe vera as the edible coating can inhibit the transfer of $\mathrm{CO}_{2}$ and $\mathrm{O}_{2}$, and also remove moisture. The use of aloe vera as an edible coating does not affect TTA in grapes, this can be caused Aloe vera gel maintain the oxygen levels. If edible coating can not maintain the oxygen levels, the respiration rate will change as well as the organic acid content.

A high and low concentration of glycerol does not give good results, since without glycerol, the fruit will be exposed to moisture, and respiration will occur so that the reduction process in the fruits will increase. However, the addition of too much glycerol does not bring a good effect either, as it can affect the weight reduction due to an increase in moisture and anaerobic respiration (Simanjorang, 2017). So the use of glycerol is not suitable to be applied to red grapes.

The total amount of acid is closely related to the $\mathrm{pH}$ value, where the increase in total acid showed a decrease in $\mathrm{pH}$. This is because the pectin can bind water, sugar, and dissolved solids such as acids in the material, which causes an increase in the total acid. This phenomenon happens since the number of sugar hydrolyzed to acid is getting higher. The increase of acid content in food can occur due to the decomposition of glucose into the acid (Cindaramaya \& Nuramalia, 2019).

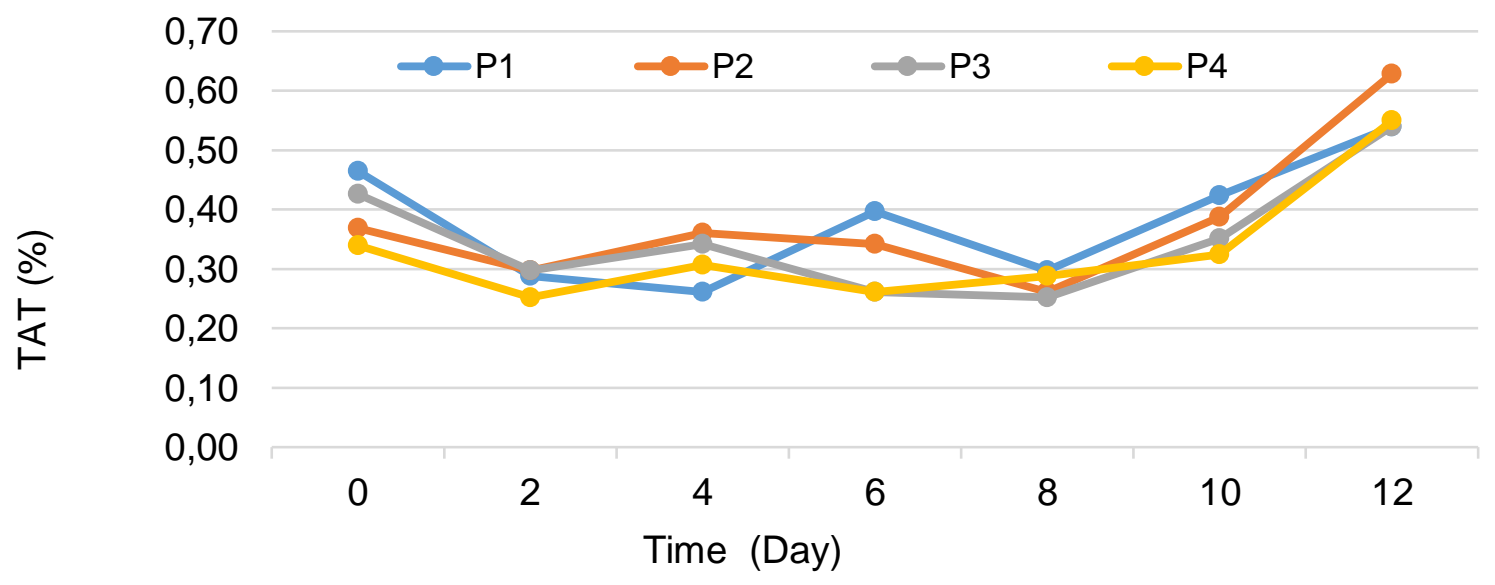

Figure 2. Chart of the impact glycerol level of edible coating on TAT

Based on the results made every two days, it is known that a decrease in TAT occurs up to day 8 , and an increase in TAT is pretty high on observation days 10 and 12 . It can be seen that the use of aloe vera as an edible coating will keep TAT up to 8 days of storage, and 
will start to increase since the 10th day of storage. Inconsistent increase and decrease of TAT value can be influenced by several factors. In the relatively high increase, this happens because the total acid value increases as a result of the anaerobic respiration and microbial fermentation that may infect the fruit because of the low content of $\mathrm{O}_{2}$ (Taringan, 2015). Meanwhile, the acid content generally decreases because it is used for respiration or converted into sugar (Taringan, 2015).

Changes in the total organic acid content of fruits and vegetables indicate there is a chemical change in these fruits and vegetables. Organic acids that are found in fruit, namely citric acid, malic acid, oxalate, tartaric acid, tamarind quinan, chlorogenic acid, shikimic acid and ascorbic acid. The type of acid measured in the TAT of grapes is tartaric acid, since tartatic acid is dominant organic acid in grape.

\section{Hedonic Test Quality (Aroma, Texture, Color) Aroma}

Table 2. The impact of edible coating on the red grapes' aroma, texture and color

\begin{tabular}{llll}
\hline Treatments & Aroma & Texture & Color \\
\hline P1 & $4.43 \pm 0.34^{\mathrm{a}}$ & $3.67 \pm 0.13^{\mathrm{ab}}$ & $3.15 \pm 0.53^{\mathrm{a}}$ \\
P2 & $4.48 \pm 0.09^{\mathrm{a}}$ & $3.55 \pm 0.05^{\mathrm{ab}}$ & $3.08 \pm 0.48^{\mathrm{a}}$ \\
P3 & $5.00 \pm 0.05^{\mathrm{b}}$ & $3.93 \pm 0.45^{\mathrm{b}}$ & $3.08 \pm 0.93^{\mathrm{a}}$ \\
P4 & $5.00 \pm 0.03^{\mathrm{b}}$ & $3.19 \pm 0.02^{\mathrm{a}}$ & $3.15 \pm 0.77^{\mathrm{a}}$ \\
\hline
\end{tabular}

Description: The same letters behind the average value shows a real different value. $(p<0.05)$ Room temperature is between $28-30^{\circ} \mathrm{C}$.

The results of the statistical analysis of the advanced Duncan test on the aroma of red grapes stored at room temperature have a significant value to the aroma after edible coating treatment with the addition of glycerol was applied. This means that the aloe vera coating used as a coating can maintain the aroma of red grapes. According to (Miskiyah et al., 2016), the coating can act as a good barrier, so that the loss of volatile components can be reduced, or the metabolism of volatile production can be affected.

Based on the observation made every 2 days until day 12, the result shows that on day 0 up to 4, the treatment of P1 and P2 glycerol had the same value. Meanwhile, the treatment of P3 and P4 glycerol from the first to the last observations had the same value, which was a very fragrant scent. Due to the long storage time of the fruit, the aroma produced was more powerful. This also happened because of the presence of the maturation process. From this phenomenon it is known that the addition of glycerol to the edible coating of aloe vera with a concentration of P3 and P4 can maintain the aroma quality of the fruit.

\section{Texture}

The results of the statistical analysis of the advanced Duncan test performed on the texture of red grapes stored at room temperature had a significant value to the texture after edible coating treatment was applied. P3 treatment had better texture where the addition of glycerol gave impact in maintaining the texture of red grapes so that the softness of the texture can be reduced. High and low values of the texture are related to weight reduction. Both happen due to inevitable transpiration and respiration process so that the process of water loss continues to occur. High weight reduction happens due to water loss and is characterized by a soft fruit texture. This is closely related to the character of the fruits, which have thin cell walls (Zumairy, 2018). 


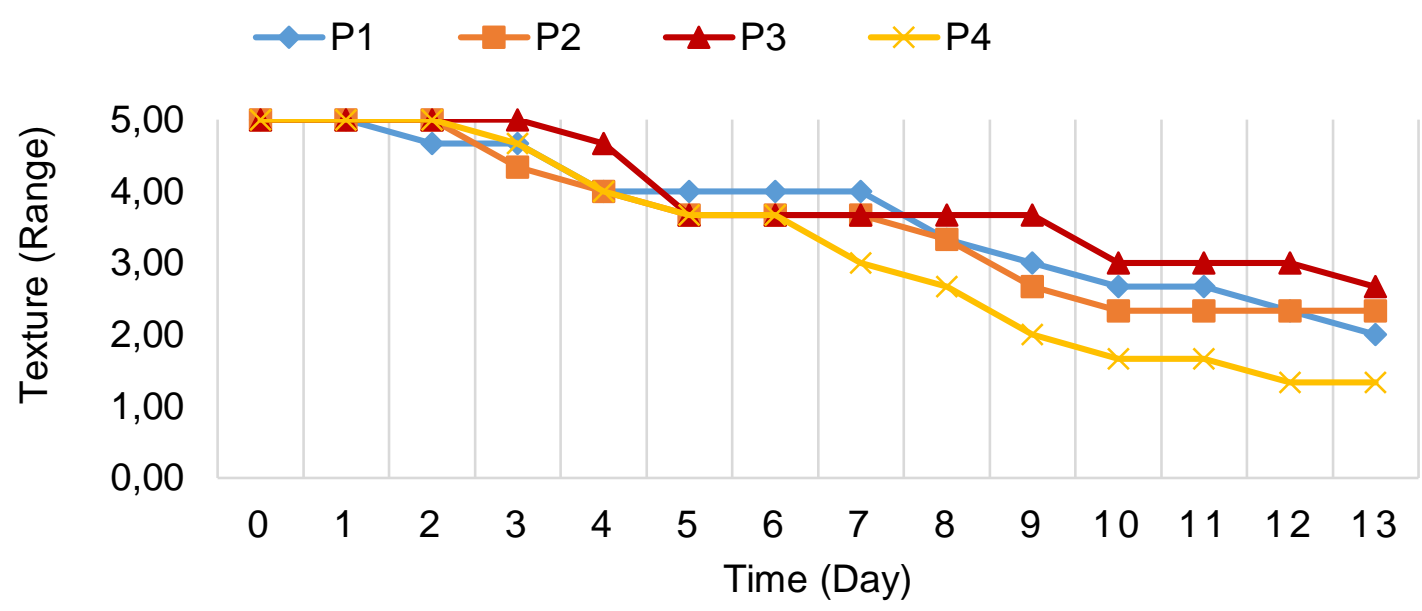

Figure 3. The chart on the impact of edible coating on the red grapes' texture

Figure 3. shows that the treatment of edible coating for 13 days generates some results: 1) the texture of the fruit decreased starting from the observation of day 3 where the hardness decrease was relatively low in the glycerol P3 treatment. Meanwhile, the hardness decrease was significantly increasing in the glycerol P4 treatment compared to the other treatments. This suggests that the softness of the texture of red grapes will develop along with the ripening of the grapes. The addition of $7 \%$ concentration glycerol could increase the moisture of the fruit so that anaerobic respiration occurs which leads to softness on the fruit.

\section{Color}

Based on the observations that have been made for 13 days, it can be seen in (Table 1.) that the color of red grapes, as measured by using the application of Color Assist was similar to the result of each treatment and observation time. The addition of glycerol treatment causes more red grapes skin surface shiny. Glycerol is a type of plasticizer is hydrophilic, adds to the polar nature, makes the surface more shiny and easily dissolves in water so that with the addition of glycerol to this coating give effect to the shiny surface of the fruit.

Thus based on the discussion of the research parameters, the addition of glycerol to the aloe vera edible coating can be considered for use as a coating for red grapes. Parameters that highly affect the quality of red grapes is texture and weight loss.

\section{CONCLUSIONS}

Based on the application result of aloe vera edible coating with the glycerol concentration which can maintain the quality of the red grapes from its physicochemical characteristics (weight reduction, $\mathrm{pH}$, titrated acid total) and hedonic quality (aroma, texture, color), it can be concluded that:

1. The lowest weight reduction was found at P3. pH measurement of red grapes for all treatment is 4 . The highest TAT was found in treatment P1 and P2.

2. The highest hedonic quality (aroma, texture, color) score was found in P3 and P4 treatment. P3 Treatment has a hard texture. Color in red grapes with the glycerol treatment indicates glossier skin surface.

3. The best result for the addition of glycerol concentration on aloe vera edible coating applied on red grapes was found in the P3 treatment since there was not too much glycerol addition in this treatment.

\section{REFERENCES}

Cindaramaya, L., \& Nuramalia, M. (2019). Pengaruh Penggunaan Asam Alami terhadap Karakteristik Sensori dan Fisikokimia Fruit Leather Labu Kuning. Jurnal Pangan dan Agroindustri, 4(1), 41-50. 
Cornelia, M. (2017). [Utilization of Durian Seed Starch (Durio zibethinus L .) as Edible Coating to Mantain the Quality of Red Grape (Vitis vinifera L .)]. Fast - Jurnal Sains dan Teknologi, $1(1), 51-67$.

Gardjito, M. dan S,A. Wardana. (2003). Holtikultura Teknik Analisis Pasca Panen. Transmedia Global Wacana. Magelang, Yogjakarta.

Kismaryanti, A. (2007). Aplikasi gel lidah buaya (Aloe vera L.) sebagai Edible Coating pada Pengawetan Tomat (Lycopersicon esculentum). Jurnal Teknologi Pertanian, 2, 12-15.

Marwina, R., Agustina, R., \& Putra, B. S. (2016). Perubahan Mutu Tomat (Lycopersicon esculentum Mill.) dengan Variasi Konsentrasi Pelapisan Gel Lidah Buaya (Aloe vera L.) dan Suhu Penyimpanan. Jurnal Ilmiah Mahasiswa, 1(1), 985-994.

Miskiyah, Widaningrum, \& Winarti, C. (2016). Aplikasi Edible Coating Berbasis Pati Sagu dengan Penambahan Vitamin C pada Paprika: Preferensi Konsumen dan Mutu Mikrobiologi. Jurnal Hortikultura, 21(1), 68. https://doi.org/10.21082/jho rt.v21n1.2011.p68-76.

Nahwi, naufal fadli. (2016). Analisis Pengaruh Penambahan Plastisizer Gliserol pada Karakteristik Edible Film dari Pati Kulit Pisang Raja, Tongkol Jagung dan Bonggol Enceng Gondok. Karya Tulis Ilmiah Teknologi Pertanian, 1(2), 100-118.

Prabawa, S., \& Sugianti, C. (2016). Kajian Ekstrak Daun Randu (Ceiba pentandra L.) Sebagai Bahan Edible Coating terhadap Sifat Fisik dan Kimia Buah Tomat Selama Penyimpanan. Jurnal Teknologi Pertanian (Vol. 10), 20-35. https://doi.org/10.24198/jt.vol10n1.3.

Prasotio, H. S. (2015). Aplikasi Edible Coating (Aloe vera L.) Kombinasi Ekstrak Jahe pada Buah Tomat Selama Penyimpanan. Universitas Lampung, 1, 30-46.

Simanjorang, R. A. (2017). Pengaruh Konsentrasi CMC dan Lama Pencelupan pada Aplikasi Lidah Buaya (Aloe vera L.) Sebagai Edible Coating pada Cabai Merah (Capsicum annum L.). Jurnal IImiah Mahasiswa. Universitas Lampung, 1-53.

Sudarmadji S, Haryono, \& Suhardi. (1997). Prosedur Analisis Untuk Bahan Makanan dan Pertanian. Yogyakarta : Liberty.

Taringan, Nirma Nopita, S. (2015). Maintaining the Quality of Fresh Tomatoes With a Coating Vegetable Oil. Jurnal Teknologi Pertanian, Universitas Udayana, 1(2), 19.https://doi.org/012003\r10.1088/1742-6596/369/1/01203.

Zumairy, M. (2018). Pengaruh Penggunaan Gum Arab pada Gel Lidah Buaya sebagai Edible Coating terhadap Sifat Fisik dan Kadar Vitamin C pada Buah Strobery. Jurnal Teknologi Pertanian, Institut Pertanian Bogor, 1(2), 109-140. 